\title{
Pelatihan Peningkatan Keterampilan Video Editing Di Sman 2 Lembang Bandung Barat
}

\author{
Cahyo Prianto $^{1}$, Nisa Hanum Harani ${ }^{2}$, Woro Isti Rahayu ${ }^{3}$ \\ ${ }^{123}$ Politeknik Pos Indonesia \\ Email: cahyoprianto@poltekpos.ac.id
}

\begin{tabular}{ll}
\hline Article History: & Abstrak: \\
Received: Mei 2021 & Perkembangan teknologi media sosial hadir \\
Revised: Juni 2021 & sebagai sarana untuk berkomunikasi, pola \\
Accepted: Juni 2021 & komunikasi jarak jauhpun hadir dengan \\
Available online: Juni & berbagai format seperti berbasis teks, suara, \\
2021 & gambar maupun video. Komunikasi didalam \\
& media sosial banyak didominasi dengan pola \\
& komunikasi visual, sehingga kemampuan \\
Kata Kunci: & mengedit gambar dan video menjadi sebuah \\
komunikasi visual, & kebutuhan agar tercipta komunikasi yang lebih \\
SMAN 2 Lembang, video & baik dan menarik. Pada pengabdian kepada \\
editing & masyarakat ini dilaksanakan dalam bentuk \\
& pelatihan dengan tema video editing yang \\
& bertujuan untuk meningkatan keterampilan \\
& komunikasi visual pengolahan video dengan \\
& mengambil objek siswa dan guru di SMAN2 \\
& Lembang Bandung Barat. Pelatihan \\
& dilaksanakan selama satu pekan yang \\
& dilakukan secara daring dengan menggunakan \\
& dua metode komunikasi yaitu tatap muka \\
& secara daring menggunakan zoom dan \\
& pendampingan peserta melalui whatsapp grup. \\
& Pelatihan mencakup materi seperti \\
& 1)Memotong video, 2)Input audio, 3)Transisi \\
& efek, 4)Clip grafis, 5)Voice over, 6)Layer \\
croma key, 7)Kemampuan edit video dan \\
gambar, 8)Ekstrak audio dari video, 9)Eksport \\
dan share video, 10)Membuat skenario film \\
pendek, 11)Memproduksi produk video. \\
Dengan menggunakan metode pretest-posttes \\
diperoleh hasil bahwa ada kenaikan nilai yang \\
signifikan antara sebelum dilakukan pelatihan \\
dengan setelah dilakukan pelatihan, sebelum \\
pelatihan tingkat pemahaman peserta untuk \\
\hline
\end{tabular}


seluruh materi sebesar $12 \%$ dan setelah pelatihan tingkat pemahaman peserta menjadi sebesar $66.5 \%$, sehingga terdapat kenaikan pemahaman peserta sebesar $53.5 \%$. Kesimpulannya adalah pelatihan yang dilakukan dapat meningkatkan pemahaman yang menunjang keterampilan komunikasi visual pengolahan video.

\section{Pendahuluan}

SMAN 2 Lembang, adalah sekolah negeri yang beralamat di Jl. Maribaya No 68 RT 04 / RW 02 Kp Sukarame Langensari Lembang, Langensari, Kec. Lembang, Kab. Bandung Barat Prov. Jawa Barat. Saat ini didalamnya terdapat 29 ruang kelas, 3 ruang laboratorium dan 1 sarana perpustakaan. Dengan jumlah guru 46 orang, mengampu 27 rombongan belajar dengan sebaran 379 siswa laki-laki dan 541 siswa perempuan (Kemdikbud, 2021). Dengan visi membangun "Sekolah Religius, Unggul, dan Kompetitif di Era Global", SMAN 2 Lembang berusaha mewujudkannya dengan upaya memberikan berbagai bekal kemampuan bagi para siswanya (fadilah, 2020; fadilah, 2020).

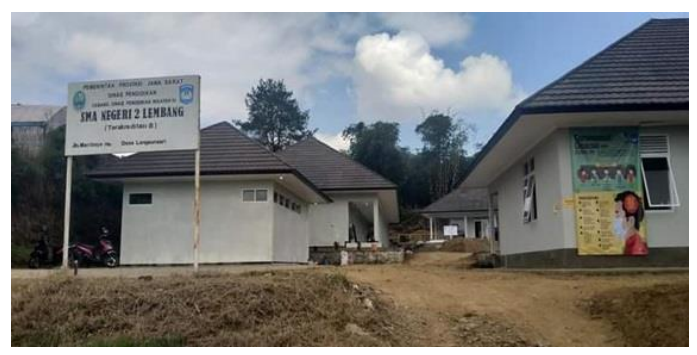

Gambar 1 SMAN 2 Lembang

Dalam era digital teknologi 4.0 ini, kemampuan berkomunikasi secara visual menjadi bagian yang sangat penting. Komunikasi didalam media sosial banyak didominasi dengan pola komunikasi visual. Komunikasi visual adalah komunikasi untuk menyampaikan pesan dengan menggunakan media yang mengandalkan indera penglihatan (Wikipedia, 2019). Komunikasi visual di definisikan sebagai payung dari berbagai komunikasi yang menggunakan 
unsur rupa (visual) pada berbagai media: percetakan / grafika, luar ruang, televisi, film / video, internet dan lain-lain (ITB, 2020) . Dewasa ini komunikasi visual sangat penting dilakukan, mengingat komunikasi visual banyak dilakukan dalam media sosial yang banyak sekali digunakan oleh masyarakat saat ini. Berdasarkan data Hootsuite yang merupakan situs layanan manajemen konten media daring yang terhubung dengan berbagai situs jejaring sosial menyebutkan bahwa pengguna media sosial aktif yang ada di indonesia berjumlah sekitar 160 juta orang (Rianto A. D., 2020).

Pentingnya kemampuan komunikasi visual, maka SMAN 2 Lembang memandang perlu adanya pelatihan peningkatan kemampuan dalam komunikasi visual khususnya dalam pengolahan gambar atau video. Dengan latar belakang tersebut, maka pelaksanaan pengabdian kepada masyarakat ini bertujuan untuk membantu meningkatkan kemampuan keterampilan komunikasi visual dalam hal pengolahan video dengan mengambil objek 25 siswa SMAN 2 Lembang.

Mengingat saat ini masih dalam kondisi pandemik Covid-19 maka pelatihan dilakukan dengan menggunakan dua metode, yaitu pertama dilakukan secara tatap muka daring melalui aplikasi zoom selama 4 kali pertemuan dan yang kedua adalah dengan menggunakan pendampingan online melalui chat pada whatsapp grup. Zoom adalah aplikasi video conference yang banyak digunakan untuk melakukan pembelajaran jarak jauh (Brahma, 2020), sedangkan whatsapp adalah aplikasi pesan instan pada smartphone yang mempunyai banyak fitur (Winarso, 2015). Sedangkan aplikasi pengolah video yang digunakan dalam Pelatihan video editing ini yaitu menggunakan video editor Kinemaster yang tersedia dalam perangkat IOS dan android (Khaira, 2020).

\section{Metode}

Pengabdian ini mengambil tema "Pelatihan Peningkatan Keterampilan Video Editing” dengan objek 25 siswa dari SMAN2 Lembang. Dilaksanakan dari tanggal 28 April - 5 Mei 2021. Adapun jadwal dan rincian kegiatan adalah sebagai berikut : 
Tabel 1 Materi dan pelaksanaan Kegiatan

\begin{tabular}{|c|c|c|c|c|c|c|}
\hline No & Materi & Kegiatan & Media & Pemateri & Waktu & Tgl \\
\hline 1 & $\begin{array}{l}\text { Pembukaan } \\
\text { Kegiatan }\end{array}$ & Pelatihan & Zoom & $\begin{array}{l}\text { Woro Istirahayu, } \\
\text { ST, MT }\end{array}$ & $13.00-13.10$ & \multirow[t]{7}{*}{$\begin{array}{l}28 \text { Juni } \\
2021\end{array}$} \\
\hline \multirow[t]{3}{*}{2} & \multirow[t]{3}{*}{$\begin{array}{l}\text { Memotong } \\
\text { Video }\end{array}$} & Pelatihan & Zoom & $\begin{array}{ll}\text { Cahyo } & \text { Prianto, } \\
\text { S.Pd,MT } & \end{array}$ & $13.10-14.10$ & \\
\hline & & Pendampingan & WAG & Nisa $\quad$ Hanum & $20.00-21.00$ & \\
\hline & & & & Harani. M.Kom & & \\
\hline \multirow[t]{3}{*}{3} & \multirow[t]{3}{*}{ Input Audio } & Pelatihan & Zoom & $\begin{array}{ll}\text { Cahyo } & \text { Prianto, } \\
\text { S.Pd,MT } & \end{array}$ & $14.10-15.00$ & \\
\hline & & pendampingan & $W A G$ & Nisa Hanum & $20.00-21.00$ & \\
\hline & & & & Harani. M.Kom & & \\
\hline \multirow[t]{3}{*}{4} & \multirow[t]{3}{*}{ Transisi Efek } & Pelatihan & Zoom & $\begin{array}{ll}\text { Cahyo } & \text { Prianto, } \\
\text { S.Pd,MT } & \end{array}$ & $13.00-13.45$ & \multirow[t]{7}{*}{$\begin{array}{l}29-04- \\
2021\end{array}$} \\
\hline & & Pendampingan & $W A G$ & Nisa $\quad$ Hanum & $20.00-21.00$ & \\
\hline & & & & Harani. M.Kom & & \\
\hline \multirow[t]{2}{*}{5} & \multirow[t]{2}{*}{ Clip Grafis } & Pelatihan & Zoom & $\begin{array}{l}\text { Cahyo Prianto, } \\
\text { S.Pd,MT }\end{array}$ & $13.45-14.20$ & \\
\hline & & pendampingan & WAG & $\begin{array}{l}\text { Nisa Hanum } \\
\text { Harani. M.Kom }\end{array}$ & $20.00-21.00$ & \\
\hline \multirow[t]{2}{*}{6} & \multirow[t]{2}{*}{ Voice Over } & Pelatihan & Zoom & $\begin{array}{l}\text { Cahyo Prianto, } \\
\text { S.Pd,MT }\end{array}$ & $14.20-15.00$ & \\
\hline & & pendampingan & WAG & $\begin{array}{l}\text { Nisa Hanum } \\
\text { Harani. M.Kom }\end{array}$ & $20.00-21.00$ & \\
\hline \multirow[t]{2}{*}{7} & \multirow[t]{2}{*}{$\begin{array}{l}\text { Layer Croma } \\
\text { key }\end{array}$} & Pelatihan & Zoom & $\begin{array}{l}\text { Cahyo Prianto, } \\
\text { S.Pd,MT }\end{array}$ & $13.00-13.45$ & \multirow[t]{6}{*}{$\begin{array}{l}30-04- \\
2021\end{array}$} \\
\hline & & pendampingan & WAG & $\begin{array}{l}\text { Nisa Hanum } \\
\text { Harani. M.Kom }\end{array}$ & $20.00-21.00$ & \\
\hline \multirow[t]{2}{*}{8} & \multirow{2}{*}{$\begin{array}{l}\text { Edit Video \& } \\
\text { Image }\end{array}$} & Pelatihan & Zoom & & $13.45-14.20$ & \\
\hline & & pendampingan & $W A G$ & $\begin{array}{l}\text { Nisa Hanum } \\
\text { Harani. M.Kom }\end{array}$ & $20.00-21.00$ & \\
\hline \multirow[t]{2}{*}{9} & \multirow{2}{*}{$\begin{array}{l}\text { Ekstrak } \\
\text { audio } \\
\text { video }\end{array}$} & Pelatihan & Zoom & $\begin{array}{l}\text { Woro Istirahayu, } \\
\text { ST, MT }\end{array}$ & $14.20-15.00$ & \\
\hline & & pendampingan & $W A G$ & $\begin{array}{l}\text { Nisa Hanum } \\
\text { Harani. M.Kom }\end{array}$ & $20.00-21.00$ & \\
\hline \multirow[t]{2}{*}{10} & \multirow[t]{2}{*}{$\begin{array}{l}\text { Ekport dan } \\
\text { share video }\end{array}$} & Pelatihan & Zoom & $\begin{array}{l}\text { Woro Istirahayu, } \\
\text { ST, MT }\end{array}$ & $13.00-13.45$ & \multirow[t]{4}{*}{$\begin{array}{l}05-05- \\
2021\end{array}$} \\
\hline & & pendampingan & WAG & $\begin{array}{l}\text { Nisa Hanum } \\
\text { Harani. M.Kom }\end{array}$ & $20.00-21.00$ & \\
\hline \multirow[t]{2}{*}{11} & $\begin{array}{l}\text { Membuat } \\
\text { skenario film } \\
\text { pendek }\end{array}$ & Pelatihan & Zoom & $\begin{array}{l}\text { Woro Istirahayu, } \\
\text { ST, MT }\end{array}$ & $13.45-14.20$ & \\
\hline & & pendampingan & WAG & Hanum & $20.00-21.00$ & \\
\hline
\end{tabular}




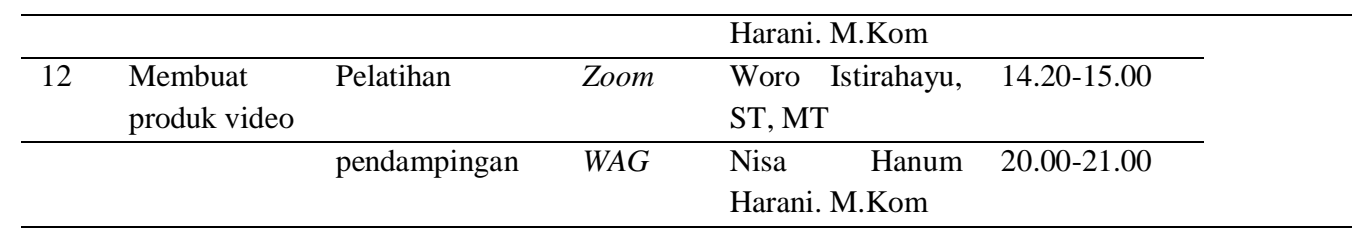

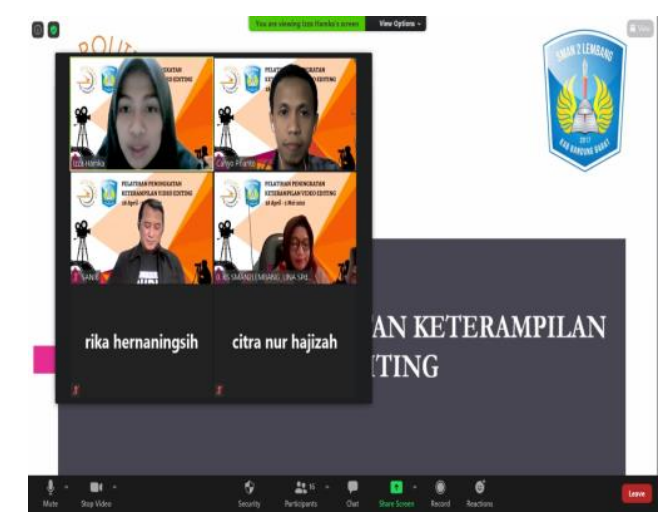

Gambar 2 Kegiatan Via Zoom

Untuk melihat efektivitas pelatihan, maka diakhir pelatihan akan dilihat adanya perubahan pemahaman peserta sekaligus penilaian produk yang dihasilkan dari pelatihan ini. Pretest dilakukan untuk melihat pemahaman awal peserta serta melihat sejauh mana peserta sudah mengetahui dan menguasai materi yang akan diberikan, kegiatan pretest dilakukan sebelum diadakan kegiatan. Setelah melalui proses pelatihan, selanjutnya adalah dilakukan postest, dimana postest ini bertujuan untuk mengetahui apakah peserta sudah mengetahui dan memahami materi yang sudah diberikan (Effendy, 2016). Postest dilakukan diakhir pelatihan. Skema pelaksanaan evaluasi diperlihatkan pada gambar 3 berikut.

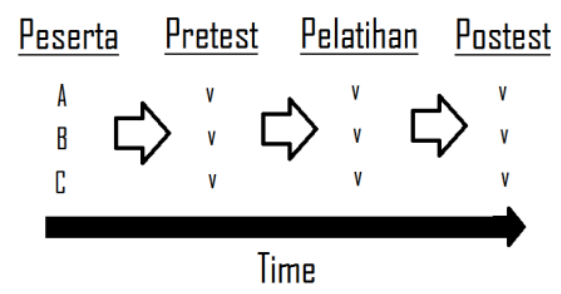

Gambar 3 Skema Evaluasi 
Untuk soal pretest-post dapat dikunjungi melalui link berikut https://bit.ly/video_editing_sman2lembang atau dapat dilihat pada gambar 4/

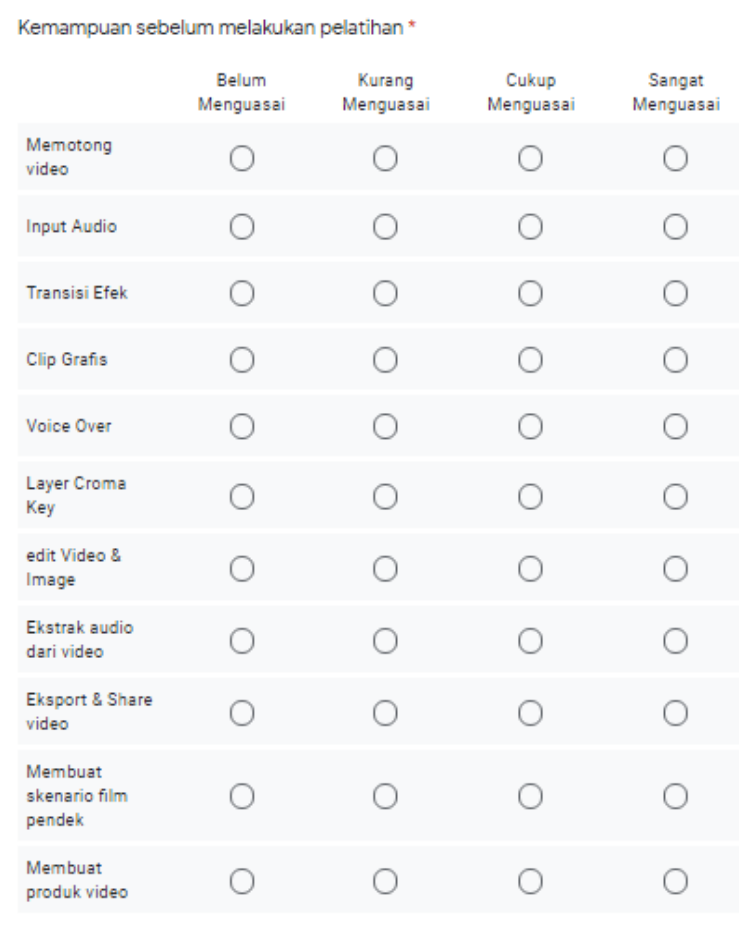

Gambar 4 Soal Pretest

\section{Hasil}

Pelatihan editing video yang dilaksanakan dengan menggunakan metode daring, mengingat saat ini masih dalam kondisi pandemi covid-19. Pelaksanaan pelatihan dengan menggunakan metode daring tentunya memberikan hasil yang kurang begitu maksimal jika dibandingkan dengan pelatihan yang dilakukan secara luring, karena proses praktek hands on yang dilakukan oleh peserta dapat secara langsung teramati. Namun demikian pelaksanaan pelatihan kami coba maksimalkan dengan memberikan pendampingan baik itu secara tatap muka langsung secara daring maupun pendampingan online menggunakan whatsapp group. Proses pelatihan sendiri dilakukan selama kurun waktu 1 pekan. Terhitung mulai tanggal 28 april -5 mei 2021. 
Untuk mengukur efektivitas pelatihan yang diberikan maka dilakukan pengukuran kemampuan sebelum dan sesudah pelatihan dalam bentuk pretest dan posttest sebagai mana yang terlihat dalam skema pada gambar 3 tentang skema evaluasi. Pada umumnya nilai evaluasi yang dihasilkan antara pemahaman awal sebelum dan sesudah pelatihan tentunya mengalami peningkatan yang siginifikan.

Untuk mengukur hasil, maka ditentukan skor dari setiap kategori pilihan pada soal pre test - post test, yaitu sebagai berikut :

Tabel 2 Nilai Skor untuk Setiap Kategori

\begin{tabular}{lll}
\hline No & Kategori & Skor \\
\hline 1 & Belum menguasai & -2 \\
\hline 2 & Kurang menguasai & -1 \\
\hline 3 & Cukup menguasai & 1 \\
\hline 4 & Sangat menguasai & 2 \\
\hline
\end{tabular}

Berikut kami sajikan hasil yang dicapai dilihat dari nilai pretest dan posttest.

Tabel 3 Hasil Capaian Sebelum dan Sesudah Pelatihan

\begin{tabular}{|c|c|c|c|c|}
\hline \multicolumn{5}{|c|}{ Keterangan Warna } \\
\hline $\begin{array}{lc}\mathrm{N} & \text { Kemam } \\
\mathrm{o} & \text { puan } \\
& \text { yang } \\
& \text { diukur } \\
\end{array}$ & $\begin{array}{c}\text { Grafik } \\
\text { Kemampuan } \\
\text { sebelum pelatihan }\end{array}$ & Poin sebelum pelatihan & $\begin{array}{c}\text { Grafik } \\
\text { Kemampuan } \\
\text { sebelum } \\
\text { pelatihan }\end{array}$ & $\begin{array}{l}\text { Kondisi } \\
\text { sebelum } \\
\text { pelatihan }\end{array}$ \\
\hline
\end{tabular}




\section{Dharma Raflesia \\ Jurnal Ilmiah Pengembangan dan Penerapan IPTEKS \\ Vol. 19, No. 01, Juni, 2021, pp. 124 - 136}

\begin{tabular}{|c|c|c|c|c|}
\hline $\begin{array}{l}1 \text { Memoto } \\
\text { ng Video }\end{array}$ & $\begin{array}{ll}20 \\
10 \\
\\
\text { Memotong video } \\
\text { - } 14 \% \text { (kurang } \\
\text { menguasai) } \\
\text { menguasai } \\
\text { 25\% Sangat } \\
\text { menguasai } \\
\end{array}$ & $\begin{array}{l}-14 \times(-1)=-14 \\
-61 \times 1=61 \\
-25 \times 2=50 \\
\text { Total poin }=97\end{array}$ & $\begin{array}{ll}10 \\
\end{array}$ & $\begin{array}{l}\bullet 4 \times(-1)=-4 \\
\bullet 34 \text { x } 1=34 \\
\bullet 61 \times 2=122 \\
\text { Total poin } 152\end{array}$ \\
\hline $2 \begin{array}{l}\text { Input } \\
\text { audio }\end{array}$ & $\begin{array}{ll}20 \\
\text { - } 4 \% \text { belum } \\
\text { menguasai } \\
\text { - } 11 \% \text { kurang } \\
\text { menguasai } \\
\text { - } 75 \% \text { cukup } \\
\text { menguasai } \\
\text { - } 4 \% \text { Sangat } \\
\text { menguasai }\end{array}$ & $\begin{array}{l}\text { - } 4 \times(-2)=-8 \\
-41 \times(-1)=-11 \\
\text { - } 75 \times 1=75 \\
\text { - } 4 \times 2=8 \\
\text { Total poin = } 64\end{array}$ & $\begin{array}{ll}10 \\
\text { - } 4 \% \text { kurang } \\
\text { menguasai } \\
\text { - } 34 \% \text { cukup } \\
\text { menguasai } \\
\text { - } 61 \% \text { Sangat } \\
\text { menguasai }\end{array}$ & $\begin{array}{l}\text { - } 4 \times(-1)=-4 \\
\text { - } 34 \times 1=34 \\
\text { - } 61 \times 2=122 \\
\text { Total poin } 152\end{array}$ \\
\hline $\begin{array}{ll}3 & \text { Transisi } \\
\text { efek }\end{array}$ & $\begin{array}{l}10 \\
\text { - } 7 \% \text { belum } \\
\text { menguasai } \\
14 \% \text { kurang } \\
\text { menguasai } \\
\text { - } 79 \% \text { cukup } \\
\text { menguasai }\end{array}$ & $\begin{array}{l}-7 \times(-2)=-14 \\
-\quad 14 \times(-1)=-14 \\
-79 \times 1=79 \\
\text { Total poin = } 51\end{array}$ & 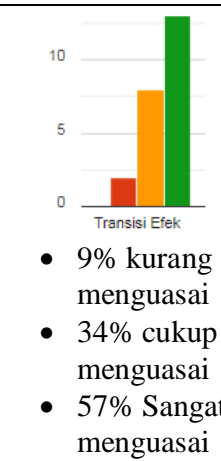 & $\begin{array}{l}\text { - } 9 \times(-1)=-9 \\
\text { - } 34 \times 1=34 \\
\text { - } 57 \times 2=114 \\
\text { Total poin = } \\
139\end{array}$ \\
\hline $4 \begin{array}{l}\text { Clip } \\
\text { grafis }\end{array}$ & $\begin{array}{l}20 \\
10 \\
\text { - } 11 \% \text { belum } \\
\text { menguasai } \\
\text { - } 14 \% \text { kurang } \\
\text { menguasai }\end{array}$ & $\begin{array}{l}-11 \times(-2)=-22 \\
-14 \times(-1)=-14 \\
-39 \times 1=39 \\
\text { Total poin = } 3\end{array}$ & $\begin{array}{ll}10 \\
\\
\text { - } 4 \% \text { kurang } \\
\text { menguasai } \\
\text { - } 49 \% \text { cukup } \\
\text { menguasai }\end{array}$ & $\begin{array}{l}\text { - } 4 \times(-1)=-4 \\
\text { - } 49 \times(1)=49 \\
\text { - } 49 \times 2=98 \\
\text { Total poin }= \\
143\end{array}$ \\
\hline
\end{tabular}




\section{Dharma Raflesia \\ Jurnal Ilmiah Pengembangan dan Penerapan IPTEKS \\ Vol. 19, No. 01, Juni, 2021, pp. 124 - 136}

\begin{tabular}{|c|c|c|c|c|c|}
\hline & & $\begin{array}{l}\text { - } 39 \% \text { cukup } \\
\text { menguasai }\end{array}$ & & $\begin{array}{l}\text { - } 49 \% \text { Sangat } \\
\text { menguasai }\end{array}$ & \\
\hline 5 & $\begin{array}{l}\text { Voice } \\
\text { Over }\end{array}$ & $\begin{array}{ll}20 \\
\\
\text { - } 14 \% \text { belum } \\
\text { menguasai } \\
\text { - } 46 \% \text { kurang } \\
\text { menguasai } \\
\text { - } 39 \% \text { cukup } \\
\text { menguasai }\end{array}$ & $\begin{array}{l}-14 \times(-2)=-28 \\
-\quad 46 \times(-1)=-46 \\
-\quad 39 \times 1=39 \\
\text { Total poin = } 35\end{array}$ & $\begin{array}{ll}10 \\
\\
\text { - } \quad 4 \% \text { kurang } \\
\\
\text { - } \quad 52 \% \text { cukup } \\
\\
\text { menguasai } \\
43 \% \text { Sangat } \\
\text { menguasai }\end{array}$ & $\begin{array}{l}\text { - } 4 \times(-1)=-4 \\
\text { - } 52 \times(1)=52 \\
\text { - } 43 \times 2=86 \\
\text { Total poin = } \\
134\end{array}$ \\
\hline 6 & $\begin{array}{l}\text { Layer } \\
\text { Croma } \\
\text { key }\end{array}$ & $\begin{array}{ll}20 \\
& 11 \% \text { belum } \\
& \text { menguasai } \\
\text { - } & 43 \% \text { kurang } \\
& \text { menguasai } \\
& 46 \% \text { cukup } \\
& \text { menguasai }\end{array}$ & $\begin{array}{l}-11 \times(-2)=-22 \\
-43 \times(-1)=-43 \\
-46 \times 1=46 \\
\text { Total poin }=-19\end{array}$ & $\begin{array}{l}10 \\
\\
\text { - } 4 \% \text { kurang } \\
\text { menguasai } \\
\text { - } 43 \% \text { cukup } \\
\text { menguasai } \\
\text { - } 52 \% \text { Sangat } \\
\text { menguasai }\end{array}$ & $\begin{array}{l}\text { - } 4 \times(-1)=-4 \\
\text { - } 43 \times(1)=43 \\
\text { - } 52 \times 1=52 \\
\text { Total poin }=91\end{array}$ \\
\hline 7 & $\begin{array}{l}\text { Edit } \\
\text { Video \& } \\
\text { Image }\end{array}$ & $\begin{array}{ll}20 \\
\\
\text { - } \quad 4 \% \text { belum } \\
\text { menguasai } \\
\text { - } 21 \% \text { kurang } \\
\text { menguasai } \\
\text { - } 57 \% \text { cukup } \\
\text { menguasai } \\
21 \% \text { Sangat } \\
\text { menguasai }\end{array}$ & $\begin{array}{l}\text { - } 4 \times(-2)=-8 \\
-\quad 21 \times(-1)=-21 \\
-\quad 57 \times 1=57 \\
-\quad 21 \times 2=42 \\
\text { Total poin }=70\end{array}$ & $\begin{array}{l}10 \\
\text { - } 4 \% \text { kurang } \\
\text { menguasai } \\
\text { - } 35 \% \text { cukup } \\
\text { menguasai } \\
\text { - } 61 \% \text { Sangat } \\
\text { menguasai }\end{array}$ & $\begin{array}{l}\text { - } 4 \times(-1)=-4 \\
\text { - } 35 \times(1)=35 \\
\text { - } 61 \times 2=122 \\
\text { Total poin = } \\
153\end{array}$ \\
\hline & $\begin{array}{l}\text { Ekstrak } \\
\text { audio } \\
\text { dari } \\
\text { video }\end{array}$ & $\begin{array}{l}20 \bar{c} \\
10 \\
\text { - } 4 \% \text { belum } \\
\text { menguasai }\end{array}$ & $\begin{array}{l}-4 \times(-2)=-8 \\
\text { - } 36 \times(-1)=-36 \\
\text { - } 43 \times 1=43 \\
\text { - } 18 \times 2=36 \\
\text { Total poin = } 35\end{array}$ & $\begin{array}{c}10 \\
0 \quad 9 \% \text { kurang } \\
\text { Esstrak audio dari } \\
\text { video } \\
\text { menguasai }\end{array}$ & $\begin{array}{l}\text { - } \quad 9 \times(-1)=-9 \\
-\quad 35 \times 1=35 \\
\text { - } 57 \times 2=114 \\
\text { Total poin = } \\
140\end{array}$ \\
\hline
\end{tabular}




\section{Dharma Raflesia \\ Jurnal Ilmiah Pengembangan dan Penerapan IPTEKS \\ Vol. 19, No. 01, Juni, 2021, pp. 124 - 136}

\begin{tabular}{|c|c|c|c|c|c|}
\hline & & $\begin{array}{l}\text { - } 36 \% \text { kurang } \\
\text { menguasai } \\
\text { - } 43 \% \text { cukup } \\
\text { menguasai } \\
\text { - } 18 \% \text { Sangat } \\
\text { menguasai }\end{array}$ & & $\begin{array}{ll} & 35 \% \text { cukup } \\
\text { menguasai } \\
\text { - } & 57 \% \text { Sangat } \\
\text { menguasai }\end{array}$ & \\
\hline 9 & $\begin{array}{l}\text { Ekport } \\
\text { dan } \\
\text { share } \\
\text { video }\end{array}$ & $\begin{array}{ll} & \\
& \\
\text { - } \quad 4 \% \text { belum } \\
\text { menguasai } \\
\text { - } 36 \% \text { kurang } \\
\text { menguasai } \\
\text { - } 43 \% \text { cukup } \\
\text { menguasai } \\
14 \% \text { Sangat } \\
\text { menguasai }\end{array}$ & $\begin{array}{l}\text { - } 4 \times(-2)=-8 \\
\text { - } 36 \times(-1)=-36 \\
\text { - } 43 \times 1=43 \\
\text { - } 14 \times 2=28 \\
\text { Total poin }=27\end{array}$ & $\begin{array}{l}10 \\
\text { - } 9 \% \text { kurang } \\
\text { menguasai } \\
\text { - } 39 \% \text { cukup } \\
\text { menguasai } \\
\text { - } 52 \% \text { Sangat } \\
\text { menguasai }\end{array}$ & $\begin{array}{c}\text { - } 9 \times(-1)=-9 \\
\text { - } 39 \times 1=39 \\
\text { - } 52 \times 2=104 \\
\text { Total poin = } \\
134\end{array}$ \\
\hline $\begin{array}{l}1 \\
0\end{array}$ & $\begin{array}{l}\text { Membu } \\
\text { at } \\
\text { skenario } \\
\text { film } \\
\text { pendek }\end{array}$ & $\begin{array}{l}20 \\
10 \\
\text { - } 7 \% \text { belum } \\
\text { menguasai } \\
\text { - } 54 \% \text { kurang } \\
\text { menguasai } \\
\text { - } 32 \% \text { cukup } \\
\text { menguasai } \\
\text { - } 7 \% \text { Sangat } \\
\text { menguasai }\end{array}$ & $\begin{array}{l}-7 \times(-2)=-14 \\
-54 \times(-1)=-54 \\
-32 \times 1=32 \\
-7 \times 2=14 \\
\text { Total poin }=-22\end{array}$ & $\begin{array}{l}10 \\
\\
\text { - } 13 \% \text { kurang } \\
\text { menguasai } \\
\text { - } 43 \% \text { cukup } \\
\text { menguasai } \\
\text { - } 43 \% \text { Sangat } \\
\text { menguasai }\end{array}$ & $\begin{array}{c}\text { - } 13 \times(-1)=-13 \\
\text { - } 43 \times 1=43 \\
\text { - } 43 \times 2=86 \\
\text { Total poin = } \\
116\end{array}$ \\
\hline $\begin{array}{l}1 \\
1\end{array}$ & $\begin{array}{l}\text { Membu } \\
\text { at } \\
\text { produk } \\
\text { video }\end{array}$ & $\begin{array}{l}20 \\
10 \\
\text { - } 14 \% \text { belum } \\
\text { menguasai } \\
\text { - } 29 \% \text { kurang } \\
\text { menguasai } \\
\text { - } 50 \% \text { cukup } \\
\text { menguasai } \\
\text { - } 7 \% \text { Sangat } \\
\text { menguasai }\end{array}$ & $\begin{array}{l}\text { - } 14 \times(-2)=-28 \\
\text { - } 29 \times(-1)=-29 \\
\text { - } 50 \times 1=50 \\
\text { - } 7 \times 2=14 \\
\text { Total poin = } 7\end{array}$ & $\begin{array}{l}10- \\
\text { - } 17 \% \text { kurang } \\
\text { menguasai } \\
\text { - } 39 \% \text { cukup } \\
\text { menguasai } \\
\text { - } 43 \% \text { Sangat } \\
\text { menguasai }\end{array}$ & $\begin{array}{c}\text { - } 17 \times(-1)=-17 \\
\text { - } 39 \times 1=39 \\
\text { - } 43 \times 2=86 \\
\text { Total poin = } \\
108\end{array}$ \\
\hline & \multicolumn{2}{|c|}{ TOTAL POINT } & 278 & & 1462 \\
\hline & \multicolumn{2}{|c|}{ Persentase } & $(278 / 2200) * 100 \%=12 \%$ & & $\begin{array}{l}(1462 / 2200)^{*} 100 \% \\
=66.5 \%\end{array}$ \\
\hline
\end{tabular}

Catatan : 2200 adalah total point maksimal yang bisa diperoleh 
Dari data yang diperlihatkan pada tabel 2 diatas, kita memperoleh hasil bahwa ada kenaikan nilai yang signifikan antara sebelum dilakukan pelatihan dengan setelah dilakukan pelatihan, sebelum pelatihan tingkat pemahaman peserta terhadap materi adalah sebesar $12 \%$ dan setelah pelatihan tingkat pemahaman peserta menjadi sebesar $66.5 \%$, sehingga terdapat kenaikan pemahaman peserta sebesar $53.5 \%$

\section{Diskusi}

Dari pengabdian yang telah dilaksanakan maka terdapat beberapa bahan yang dapat didiskusikan yaitu,

a. Proses pelaksanaan pelatihan pada pengabdian kepada masyarakat ini mengikuti pola seperti yang terlihat pada gambar 5 berikut :

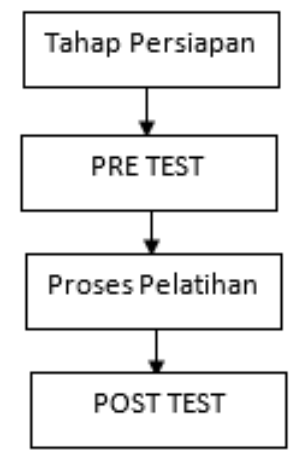

Gambar 5. Proses Kegiatan PKM

Tahap persiapan adalah tahap yang dimulai dari mulai perancangan kegiatan sampai persiapan pelaksanaan kegiatan, seperti penyusunan materi, proses penandatanganan kesepakatan bersama mitra / objek PKM serta penyiapan proses pre test dan post test. Kemudian dilanjutkan dengan 
tahap pretest untuk mengukur kemampuan awal peserta yang nanti akan dibandingkan dengan hasil yang diperoleh pada tahap terakhir yang dilakukan yaitu post test. Tahap pelaksanaan sendiri adalah tahap inti dimana proses utama pelatihan dilaksanakan.

b. Pelatihan yang dilakukan menggunakan mode daring akan memerlukan waktu yang lebih banyak untuk menghindari kendala-kendala seperti sulitnya akses internet atau jaringan yang terputus-putus.

c. Setelah dilakukan pelatihan secara teknis video editing, maka materi yang dapat menjadi rekomendasi sebagai kelanjutan dari pelatihan ini adalah bagaimana memunculkan ide kreatif

\section{Kesimpulan}

Adapun kesimpulan yang dapat diambil dari kegiatan ini adalah sebagai berikut :

a. Kita memperoleh hasil bahwa ada kenaikan nilai yang signifikan antara sebelum dilakukan pelatihan dengan setelah dilakukan pelatihan, sebelum pelatihan tingkat pemahaman peserta terhadap materi adalah sebesar $12 \%$ dan setelah pelatihan tingkat pemahaman peserta menjadi sebesar $66.5 \%$, sehingga setelah pelatihan terdapat kenaikan pemahaman peserta sebesar $53.5 \%$.

b. Pelatihan yang dilaksanakan secara signifikan dapat meningkatkan pemahaman yang menunjang keterampilan komunikasi visual pengolahan video.

\section{Pengakuan/Acknowledgements}

Penulis mengucapkan terimakasih kepada berbagai pihak yang telah memberikan bantuan atas terlaksananya pengabdian ini. Khususnya kepada 
Lembaga Penelitian dan Pengabdian kepada Masyarakat POLTEKPOS serta mitra pengabdian SMAN2 Lembang.

\section{Daftar Referensi}

Brahma, I. A. (2020). Penggunaan Zoom Sebagai Pembelajaran Berbasis Online Dalam Mata Kuliah. Jurnal Ilmu Pendidikan Nonformal Aksara, 97-102.

Effendy, I. (2016). Pengaruh Pemberian Pre-Test Dan Post-Test Terhadap Hasil Belajar Mata Diklat Hdw.Dev.100.2.A. Pada Siswa Smk Negeri 2 Lubuk Basung. Volt Jurnal Ilmiah Pendidikan Teknik Elektro, 8182.

Fadilah, N. A. (2020). Sman 2 Lembang, "Sekolah Rasa Pesantren". Bandung: Http://Disdik.Jabarprov.Go.Id.

Itb, F. (2020). Kk Komunikasi Visual Dan Multimedia. Bandung: Https://Fsrd.Itb.Ac.Id/Kelompok-Keahlian/Komunikasi-Visual-DanMulti-Media/.

Kemdikbud, T. D. (2021). Sma Negeri 2 Lembang. Http://Sekolah.Data.Kemdikbud.Go.Id/Index.Php/Chome/Profil/9255 d003-32e3-439a-932c-F1d6be5a9155.

Khaira, H. (2020). Pemanfaatan Aplikasi Kinemaster Sebagai. Prosiding Seminar Nasional Pbsi-Iii, 39-44.

Rianto, A. D. (2020). Hootsuite (We Are Social) : Indonesia Digital Report. Retrieved Maret 15, 2021, From Https://Andi.Link/Hootsuite-WeAre-Social-Indonesian-Digital-Report-2020/

Rianto, A. D. (2020). Hootsuite (We Are Social) : Indonesia Digital Report. Retrieved From Https://Andi.Link/Hootsuite-We-Are-SocialIndonesian-Digital-Report-2020/

Wikipedia. (2019). Komunikasi

Visual. Https://Id.Wikipedia.Org/Wiki/Komunikasi_Visual.

Winarso, B. (2015). Apa Itu Whatsapp. Retrieved From Dailysocial.Id: Https://Dailysocial.Id/Post/Apa-Itu-Whatsapp 